DOI: $10.21802 /$ artm.2019.4.12.110.

УДК 575.191+616-005.6+616-089+616.13+617.58

\title{
ПРЕДИКТОРИ ТРОМБОЗІВ ШУНТІВ У ПАЦІЕНТІВ 3 АТЕРОСКЛЕРОТИЧНИМИ ОКЛЮЗІЙНО-СТЕНОТИЧНИМИ УРАЖЕННЯМИ АРТЕРІЙ НИЖНІХ КІНЦІВОК
}

\author{
Р.В.Сабадош, В.А. Решетило, О.Ф. Совтус, В.В. Мотуз, С.В. Сарапук, Н.М. Ризюк \\ Івано-Франківський національний медичний університет, кафедра хірургії стоматологічного \\ факультету, м. Івано-Франківськ, Украӥна, \\ ORCID ID: 0000-0001-9770-5960, ORCID ID: 0000-0001-6216-3524, \\ ORCID ID: 0000-0001-9125-7570, ORCID ID: 0000-0002-9369-7518, \\ ORCID ID: 0000-0001-8678-8801, ORCID ID: 0000-0003-0364-666X, \\ e-mail:r.sabadosh@gmail.com
}

Резюме. Метою дослідження стало покращення лікування пацієнтів 3 облітеруючим атеросклерозом нижніх кінцівок, яким проводяться відкриті шунтуючі оперативні втручання на артеріях, шляхом вивчення частоти та причин тромбозів шунтів після реконструктивних операцій на різних артеріальних сегментах. Впродовж 3 років динамічно спостерігалися 93 такі хворі. У 81 хворого були виконані «одноповерхові» артеріальні реконструктивні втручання і у 12 - «двоповерхові». Було виявлено, що в осіб, у яких упродовж спостереження шунти затромбувалися, швидкість агрегації тромбоцитів та рівень фактора Віллебранда перед операцією були статистично значуще вищими, ніж у хворих без тромбозів шунтів ( $\mathrm{p}=0,037$ та 0,048$)$. Частота тромбозів шунтів була також статистично значуще вищою у осіб 3 доопераційним активованим частковим тромбопластиновим часом, відхиленим у бік гіперкоагуляції $(\mathrm{p}=0,039)$. Серед осіб зі стенозами 50-70 \% в аорто-клубовому сегменті та протяжними оклюзіями у стегново-підколінному сегменті, яким реконструктивні операції виконували лише на стегново-підколінному сегменті, частота тромбозів шунтів виявилася статистично значуще вищою, ніж у осіб, у яких стенози в аорто-клубовому сегменті були попередньо ліквідовані шляхом стентування зовнішньої чи загальної клубової артерії ( $(\mathrm{p}=0,041)$. Було також встановлено, що при відсутності адекватної вени, для стегново-підколінних шунтувань 3 дистальним анастомозом вище коліна допустимо використовувати алошунтування, а для стегново-гомілкових реконструкцій - алоаутошунтування. Проведення нового дослідження 3 вивченням частоти тромбозів шунтів у випадку протидії виявленим у цій праці предикторам може зумовити суттєве покращення результатів лікування таких хворих.

Ключові слова: облітеруючий атеросклероз, тромбози шунтів, гемостаз.

Вступ. У 2010 році було підраховано, що у світі облітеруючим атеросклерозом нижніх кінцівок хворіє більше 200 млн осіб, причому їх кількість порівняно з 2000 роком зросла на 23,5\% [1]. Критична ішемія нижньої кінцівки виникає у близько 3 \% таких пацієнтів, призводячи в межах 1 року до ампутації кінцівки у $30 \%$ осіб та до смерті у $25 \%$ [2]. Не дивлячись на швидкий розвиток ендоваскулярних технологій, основним методом лікування пацієнтів 3 протяжними оклюзійно-стенотичними ураженнями артерій нижніх кінцівок та пацієнтів 3 невдалими ендоваскулярними втручаннями залишаються відкриті реконструктивні операції (протезування і шунтування) [3]. Недоліком цих втручань є те, що частота віддалених тромбозів шунтів залишається високою: від 20,9 $\%$ до $42 \%[4,5]$. Загалом, саме тромбози шунтів $\epsilon$ найчастішим ускладненням після вказаних операцій: 60,2 \% серед усіх ускладнень [6].

Обгрунтування дослідження. Враховуючи вищесказане, проблему тромбозів артеріальних шунтів при оклюзійно-стенотичних атеросклеротичних ураженнях артерій нижніх кінцівок можна вважати однією 3 найважливіших проблем сучасної судинної хірургії. На сьогодні всі найважливіші аспекти профілактики тромбозів артеріальних шунтів зібрані у всесвітніх рекомендаціях, виданих під егідою
«Society for Vascular Surgery», «European Society for Vascular Surgery» i «World Federation of Vascular Societies» [3]. Разом 3 тим, чимала кількість питань залишається невисвітленою, а існуючі рекомендації часто мають низький рівень доказової бази. Серед можливих шляхів розв'язання вказаної проблеми перспективними напрямками дослідження можна вважати: пошук передопераційних предикторів тромбозів шунтів серед показників судиннотромбоцитарного та коагуляційного гемостазу, а також серед функціональних характеристик постоклюзійного кровотоку; пошук оптимального матеріалу для стегново-підколінного шунтування 3 дистальним анастомозом вище та нижче коліна та для гомілкових шунтувань при відсутності необхідної аутовени; визначення оптимального місця формування проксимального анастомозу при гомілкових реконструкціях; встановлення чітких показів до проведення «одно-» чи «двоповерхового» шунтування при одночасному ураженні аорто-клубового та стегново-підколінного сегментів і стегново-підколінного та периферичного сегментів. Вищевказані аспекти визначили мету i завдання дослідження.

Мета дослідження: покращити лікування пацієнтів 3 облітеруючим атеросклерозом нижніх кінцівок, яким проводяться відкриті шунтуючі опера- 
ції на артеріях, шляхом вивчення частоти і причин тромбозів шунтів після реконструктивних операцій на різних артеріальних сегментах.

Методи і матеріали. Динамічно спостерігалися 93 хворі з облітеруючим атеросклерозом нижніх кінцівок, яким були проведені шунтуючі реконструктивні операції на артеріях різних сегментів. Спостереження розпочиналося 3 моменту встановлення показів до відкритого хірургічного втручання та отримання згоди хворого і завершувалося при справдженні однієї з трьох умов: 1) якщо 3 моменту операції пройшло 3 роки; 2) якщо стався тромбоз шунта; 3) якщо у пацієнта збереглися або заново виникли симптоми ішемії, які зумовили у нього виконання ще однієї реконструктивної операції.

Серед пацієнтів - 82 чоловіків (88,2 \%) і 11 жінок (11,8 \%). Середній вік хворих - 64,4 роки. Оклюзійно-стенотичні ураження виключно аортоклубового артеріального сегмента мали лише 3 пацієнти, одночасно аорто-клубового та стегновопідколінного - 13, виключно стегново-підколінного 27, одночасно стегново-підколінного і периферичного - 35, виключно периферичного - 3, одночасно аорто-клубового, стегново-підколінного і периферич- ного - 12. Тут слід зазначити, що 9 з вищевказаних пацієнтів були включені в наше дослідження після проведення нами корекції їх аорто-клубового сегмента шляхом ендоваскулярного втручання (стентування зовнішньої клубової артерії - 8 випадків та загальної клубової артерії - 1 випадок) при їх стенозах $>50 \%$. Відповідно, при включенні їх в дослідження вважалося, що вони вже не мають ураження аорто-клубового сегмента. Пацієнти, у яких були покази до ліквідації оклюзійно-стенотичного процесу у стегновопідколінному чи периферичному артеріальних сегментах шляхом стентування чи ангіопластики, в дослідження не включалися.

Серед осіб з патологією аорто-клубового сегмента 9 хворих мали його двобічне ураження, а решта - однобічне. Враховуючи це, у 93 хворих 102 нижні кінцівки мали хронічну артеріальну недостатність (XАH) класів IIB-IV за Fontaine. Переміжна кульгавість класу ІІБ спостерігалася на 14 кінцівках, а на решті кінцівок - критична ішемія: на 34 кінцівках класу III і на 50 - класу IV.

Спектр гнійно-некротичних ускладнень на 50 кінцівках з XАН IV класу представлений у табл. 1.

Спектр гнійно-некротичних ускладнень у паціснтів з XAH IV ступеня

Таблиця 1

\begin{tabular}{|l|l|c|}
\hline № 3/п & Вид гнійно-некротичного процесу & $\begin{array}{l}\text { Частота гнійно-некротичного процесу, } \mathrm{n} \\
(\%)\end{array}$ \\
\hline 1 & волога гангрена 1 пальця & $7(14,0 \%)$ \\
\hline 2 & волога гангрена кількох пальців & $2(4,0 \%)$ \\
\hline 3 & волога гангрена кукси пальця & $1(2,0 \%)$ \\
\hline 4 & суха гангрена 1 пальця & $8(16,0 \%)$ \\
\hline 5 & суха гангрена кількох пальців & $6(12,0 \%)$ \\
\hline 6 & остеомієліт фаланг пальця & $1(2,0 \%)$ \\
\hline 7 & сухий некроз шкіри гомілки & $1(2,0 \%)$ \\
\hline 8 & сухий некроз шкіри стопи & $5(10,0 \%)$ \\
\hline 9 & сухі некрози шкіри пальців & $5(10,0 \%)$ \\
\hline 10 & трофічна виразка гомілки & $8(16,0 \%)$ \\
\hline 11 & трофічна виразка стопи & $4(8,0 \%)$ \\
\hline 12 & трофічні виразки пальців & $1(2,0 \%)$ \\
\hline 13 & флегмона стопи & $1(2,0 \%)$ \\
\hline Всього & & $50(100 \%)$ \\
\hline
\end{tabular}

Перед операцією хворим:

- проводили агрегометрію (для оцінки стану судинно-тромбоцитарного гемостазу);

- визначали скринінгові показники коагуляційного гемостазу: активований частковий тромбопластиновий час (АЧТЧ), міжнародне нормалізоване відношення (МНВ), тромбіновий час (ТЧ), рівень фібриногену плазми крові (ФГ).

Агрегометрія виконувалася на агрегометрі «AP 2110» («SOLAR», Білорусь) з використанням як активатора АДФ в концентрації 10 мкмоль/л. Під час iii проведення розраховували кількість тромбоцитів у 1 л крові хворих, рівень фактора Віллебранда та ступінь, час і швидкість агрегації тромбоцитів.

АЧТЧ визначали для оцінки І-ої фази коагуляційного гемостазу, МНB - II-ої, а ТЧ та ФГ - III-ої.
Визначення АЧТЧ, МНВ і ТЧ виконували коагулометричними методиками (коагулометр HUMACLOTDUO, «Human GmbH», Німеччина). Використовували набори реактивів наступних виробників: для АЧТЧ - «Технология-стандарт» (РФ), а для МНВ і ТЧ - «Ренам» (РФ). Концентрацію ФГ в плазмі крові хворих визначали суховаговим методом з використанням торсійної ваги «ВТ-500» («КзАП», Україна).

У 81 хворого були виконані «одноповерхові» артеріальні реконструктивні втручання і у 12 - «двоповерхові». Спектр «одноповерхових» втручань представлений у табл. 2.

Спектр «двоповерхових» реконструктивних операцій наведено у табл. 3 . 
Таблиця 2

Спектр «одноповерхових» шунтувань у досліджуваних паціснтів

\begin{tabular}{|c|c|c|c|}
\hline $\begin{array}{l}\text { № } \\
\text { 3/ח }\end{array}$ & \multicolumn{2}{|l|}{ Вид шунтування: } & $\begin{array}{l}\text { Кількість } \\
\text { операцій (\%) }\end{array}$ \\
\hline 1 & \multicolumn{2}{|c|}{ протезування аорти та загальних клубових артерій } & $1(1,2 \%)$ \\
\hline 2 & \multicolumn{2}{|c|}{ аорто-біфеморальні алопротезування } & $5(6,2 \%)$ \\
\hline 3 & \multicolumn{2}{|c|}{ аорто-біфеморальні алошунтування } & $3(3,7 \%)$ \\
\hline 4 & \multicolumn{2}{|c|}{ аорто-стегнові однобічні алошунтування } & $4(4,9 \%)$ \\
\hline 5 & \multicolumn{2}{|c|}{ загальноклубово-глибокостегнове алошунтування } & $1(1,2 \%)$ \\
\hline 6 & \multicolumn{2}{|c|}{ зовнішньоклубово-глибокостегнове алошунтування } & $1(1,2 \%)$ \\
\hline 7 & \multicolumn{2}{|c|}{ перехресне зовнішньоклубово-загальностегнове алошунтування } & $1(1,2 \%)$ \\
\hline 8 & \multicolumn{2}{|c|}{ перехресне загальностегново-загальностегнове алошунтування } & $2(2,5 \%)$ \\
\hline \multirow[t]{5}{*}{9} & \multirow{5}{*}{$\begin{array}{l}\text { загальностегново-підколінні } \\
\text { протезування та шунтуван- } \\
\text { ня вище коліна }\end{array}$} & алопротезування & $1(1,2 \%)$ \\
\hline & & алошунтування & $5(6,2 \%)$ \\
\hline & & аутовенозне шунтування & $10(12,3 \%)$ \\
\hline & & алоаутошунтування & $1(1,2 \%)$ \\
\hline & & $\begin{array}{l}\text { аутовенозне шунтування з ендартеректомією з зовнішньої } \\
\text { клубової артерії }\end{array}$ & $1(1,2 \%)$ \\
\hline \multirow[t]{3}{*}{10} & \multirow{3}{*}{$\begin{array}{l}\text { загальностегново-підколінні } \\
\text { шунтування нижче коліна }\end{array}$} & алошунтування & $4(4,9 \%)$ \\
\hline & & аутовенозне шунтування & $13(16,1 \%)$ \\
\hline & & алоаутошунтування & $5(6,2 \%)$ \\
\hline 11 & \multicolumn{2}{|c|}{ поверхневостегново-поверхневостегнове алопротезування } & $1(1,2 \%)$ \\
\hline \multirow[t]{2}{*}{12} & \multirow{2}{*}{$\begin{array}{l}\text { поверхневостегново- } \\
\text { підколінні шунтування } \\
\text { вище коліна }\end{array}$} & алошунтування & $1(1,2 \%)$ \\
\hline & & алоаутошунтування & $1(1,2 \%)$ \\
\hline 13 & \multicolumn{2}{|c|}{ поверхневостегново-підколінні аутовенозні шунтування нижче коліна } & $3(3,7 \%)$ \\
\hline 14 & \multicolumn{2}{|c|}{ підколінно (вище коліна)-підколінне (нижче коліна) аутовенозне шунтування } & $1(1,2 \%)$ \\
\hline 15 & \multicolumn{2}{|c|}{ зовнішньоклубово-передньовеликогомілкове алоаутошунтування } & $1(1,2 \%)$ \\
\hline \multirow[t]{3}{*}{16} & \multirow{3}{*}{$\begin{array}{l}\text { загальностегново-гомілкові } \\
\text { шунтування }\end{array}$} & алошунтування до тібіоперонеального стовбура & $2(2,5 \%)$ \\
\hline & & аутовенозні шунтування до задньої великогомілкової артерії & $1(1,2 \%)$ \\
\hline & & $\begin{array}{l}\text { аутовенозні шунтування до передньої великогомілкової ар- } \\
\text { терії }\end{array}$ & $1(1,2 \%)$ \\
\hline \multirow[t]{3}{*}{17} & \multirow{3}{*}{$\begin{array}{l}\text { поверхневостегново- } \\
\text { гомілкові шунтування }\end{array}$} & алошунтування до тібіоперонеального стовбура & $1(1,2 \%)$ \\
\hline & & аутовенозне шунтування до тібіоперонеального стовбура & $1(1,2 \%)$ \\
\hline & & аутовенозні шунтування до задньої великогомілкової артерії & $2(2,5 \%)$ \\
\hline \multirow[t]{2}{*}{18} & \multirow{2}{*}{$\begin{array}{l}\text { підколінно (вище коліна)- } \\
\text { гомілкові аутовенозні про- } \\
\text { тезування }\end{array}$} & до тібіоперонеального стовбура & $2(2,5 \%)$ \\
\hline & & до задньої великогомілкової артерії & $1(1,2 \%)$ \\
\hline \multirow[t]{2}{*}{19} & \multirow{2}{*}{$\begin{array}{l}\text { підколінно (нижче коліна)- } \\
\text { гомілкові аутовенозні шун- } \\
\text { тування }\end{array}$} & до тібіоперонеального стовбура & $2(2,5 \%)$ \\
\hline & & до задньої великогомілкової артерії & $2(2,5 \%)$ \\
\hline \multicolumn{3}{|c|}{ Всього } & $81(100 \%)$ \\
\hline
\end{tabular}

Таблиця 3

Спектр «двоповерхових» шунтувань у досліджуваних паціснтів

\begin{tabular}{|l|l|c|}
\hline $\begin{array}{l}\text { № } \\
3 / п\end{array}$ & Вид шунтування & $\begin{array}{l}\text { Кількість } \\
\text { операцій (\%) }\end{array}$ \\
\hline 1 & аорто-поверхневостегново-глибокостегново-підколінне (вище коліна) алоаутошунтування & $1(8,3 \%)$ \\
\hline 2 & зовнішньоклубово-загальностегново-підколінне (нижче коліна) алоаутошунтування & $1(8,3 \%)$ \\
\hline 3 & зовнішньоклубово-глибокостегново-передньовеликогомілкове алоаутошунтування & $1(8,3 \%)$ \\
\hline 4 & загальностегново-підколінно (вище коліна)-тібіоперонеальне аутовенозне шунтування & $1(8,3 \%)$ \\
\hline 5 & загальностегново-підколінно (вище коліна)-задньовеликогомілкове алоаутошунтування & $3(25,0 \%)$ \\
\hline 6 & загальностегново-підколінно (нижче коліна)-малогомілкове алоаутошунтування & $1(8,3 \%)$ \\
\hline 7 & загальностегново-підколінно (нижче коліна)-тильностопне алоаутошунтування & $1(8,3 \%)$ \\
\hline 8 & повехневостегново-підколінно (нижче коліна)-тібіоперонеальне аутовенозне шунтування & $1(8,3 \%)$ \\
\hline 9 & повехневостегново-передньовеликогомілково-тібіоперонеальне аутовенозне шунтування & $2(16,7 \%)$ \\
\hline Всього & $12(100 \%)$ \\
\hline
\end{tabular}


Вибір відкритого оперативного втручання здійснювався на основі наступних підходів. В переважній більшості випадків використовували шунтування (проксимальний анастомоз «кінець в бік»). Протезування (проксимальний анастомоз «кінець в кінець») виконували лише в тому випадку, коли одразу дистальніше місця формування проксимального анастомозу кровотік був відсутній. Для операцій на аорто-клубовому сегменті використовувалося алошунтування, а на інших сегментах перевага надавалася аутовенозному шунтуванню (при відсутності достатнього фрагмента вени - алоаутошунтуванню, при цілковитій відсутності задовільної аутовени - алошунтуванню). При стенозах в аорто-клубовому сегменті менше 70 \% (з чіткою пульсацією на загальній стегновій артерії при іiі пальпації) його корекцію не здійснювали. У пацієнтів з оклюзіями 2 чи 3 артеріальних сегментів «двоповерхові» реконструктивні операції виконували тоді, коли був сумнів щодо адекватності відтоку в постпротезній ділянці артеріального русла після реконструкції найпроксимальнішого ураженого сегмента (слабкий ретроградний кровотік в ділянці запланованого дистального анастомозу).

Під час реконструктивних операцій на аортоклубовому артеріальному сегменті з дистальним анастомозом на загальній стегновій артерії інтраопераційно вимірювали систолічний, діастолічний і середній внутрішньоартеріальний тиск у цій артерії за допомогою монітора пацієнта 3 функцією вимірювання інвазивного тиску «ЮМ-300-20» (Україна, «ЮТАС») та систолічний, діастолічний і середній артеріальний тиск на плечі 3 розрахунком їх відношення.

Після операції хворі приходили на огляди через 3, 6, 9, 12, 18 і 24 місяці, а також позапланово у випадку погіршення стану нижньої кінцівки.

Під час оглядів у хворих вивчали:

- прохідність шунта (шляхом проведення ультразвукового тріплексного сканування за допомогою ультразвукових апаратів «LOGIQ е» (GE Healthcare, Великобританія) та «TOSHIBA ffa580a/f7» (TOSHIBA, Японія) з використанням лінійних датчиків 3 діапазоном частот 4,0-10,0 МГц та конвексних датчиків 3 діапазоном частот 2,0-5,5 МГц);

- наявність симптомів ішемії (переміжна кульгавість, біль у стопі в спокої);

- наявність незагоєних ран після оперативних втручань в ділянках первинних гнійно-некротичних уражень або виникнення нових уражень.

Під час огляду проводилася ретельна корекція чинників ризику (відсутність куріння, контроль за артеріальним тиском, рівнем глікозильованого гемоглобіну, показниками ліпідограми та вагою тіла) та контроль за прийомом антитромбоцитарних середників і статинів.

При виявленні тромбозу шунта або симптомів ішемії, які зумовили у пацієнта виконання ще однієї реконструктивної операції, дата цієї події вважалася датою закінчення спостереження. Хворому при цьому проводили подальше лікування, включаючи повторні реконструктивні операції на артеріях, але всі ці події уже не були предметом даного дослідження.

Аналізуючи результати дослідження, вивчали вплив на частоту тромбозів шунтів наступних параметрів: лограми;

1) вихідних скринінгових показників коагу-

2) вихідних показників агрегатограми;

3) попередньої ліквідації стенозів 50-70 \% у аорто-клубовому сегменті перед шунтуючими операціями на стегново-підколінному сегменті;

4) виду матеріалу, обраного для стегновопідколінного шунтування 3 дистальним анастомозом вище та нижче коліна та для гомілкових шунтувань;

5) місця формування проксимального анастомозу при гомілкових шунтуваннях;

6) проведення «одно-» чи «двоповерхового» шунтування при одночасному ураженні аортоклубового та стегново-підколінного сегментів і стегново-підколінного та периферичного сегментів.

Тут слід зауважити, що у частини пацієнтів реконструкція лише аорто-клубового сегмента при його одночасному ураженні зі стегново-підколінним сегментом не призвела до ліквідації симптомів ішемії і в подальшому їм була проведена реконструкція ще й стегново-підколінного сегмента. Порівнюючи стегново-плечовий індекс цих пацієнтів і ідентичних хворих, у яких симптоми ішемії були ліквідовані вже після аорто-клубової реконструкції, досліджували, чи існує таке значення цього показника, яке могло б інтраопераційно свідчити про необхідність доповнення аорто-клубової реконструкції стегновопідколінною.

Для статистичної обробки інформації формували базу даних в редакторі «Microsoft Excel 2013» (Microsoft, CША), встановлену з підпискою нашого університету на хмаринку «оffice 365». Крім вищевказаного редактора, для статистичної обробки даних використано програмне забезпечення «STATISTICA 10» (StatSoft, CШA).

Частоту якісних показників представляли в абсолютних (n) і відносних (\%) частотах. Порівняння 2 незалежних груп за якісним бінарним показником здійснювали за точним критерієм Fisher.

При аналізі кількісних даних обов'язково визначали характер розподілу значень показника, використовуючи для цього найбільш строгий 3 відомих методів - Shapiro-Wilk's W тест. Для кількісних даних 3 нормальним розподілом результати представля-

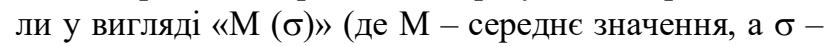
середнє квадратичне відхилення), а для кількісних даних $з$ ненормальним розподілом - у вигляді «медіана (1 і 3 квартилі)».

Кількісні показники 3 нормальним розподілом значень у 2 незалежних групах порівнювали за критерієм t-Studenta, а кількісні показники з ненормальним розподілом - методом Mann-Whitney U.

Критичний рівень значущості (p) при перевірці статистичних гіпотез у дослідженні приймали рівним 0,05 .

У дослідженні дотримані принципи Хельсінкської декларації з біомедичних досліджень (1974), 
адаптованої на 41-й Міжнародній асамблеї у Гонконзі (1989), а також принципи відношення до осіб, які виступають суб' єктами обстеження, викладені у Белмонтській доповіді (18.04.1979). Дотримання біоетичних вимог у науковому дослідженні підтверджено експертним висновком комісії з питань етики ІваноФранківського національного медичного університету.

Результати дослідження. При дослідженні доопераційних показників агрегатограми було виявлено, що ступінь і час агрегації, а також кількість тромбоцитів у пацієнтів, у яких в подальшому сталися тромбози шунтів, статистично значуще не відрізнялися від значень цих показників у осіб без їх тромбозів. Натомість швидкість агрегації у осіб із тромбозами була статистично значуще вищою, ніж у хворих без тромбозів: 65,3\%/хв $(\sigma=22,6 \% / \mathrm{xв})$ проти 29,6 $\% / \mathrm{xв}(\sigma=31,5 \% / \mathrm{xв})(\mathrm{p}=0,037)$. Аналогічно, рівень фактора фон Віллебранда був статистично значуще вищим у осіб з тромбозами: $183,6 \%$ ( $\sigma=25,9 \%)$ проти $107,25 \%(\sigma=81,4 \%)(0,048)$. Таким чином, було виявлено, що у осіб із прискореною агрегацією тромбоцитів та підвищеним рівнем фактора фон Віллебранда частота тромбозів шунтів $\epsilon$ вищою.

Результати дослідження скринінгових показників коагулограми показали, що доопераційні МНВ та ТЧ у жодного пацієнта не були відхилені в бік гіперкоагуляції. Натомість АЧТЧ було відхилене в бік гіперкоагуляції в 11 осіб (11,8\%), а ФГ - у 24 $(25,8 \%)$. Серед осіб із підвищеним рівнем ФГ частота тромбозів шунтів статистично значуще не відрізнялася від осіб із його нормальним рівнем $(\mathrm{p}>0,05)$. Натомість серед осіб з нормальним чи відхиленим у бік гіпокоагуляції рівнем АЧТЧ частота тромбозів шунтів була статистично значуще меншою, ніж у осіб 3 АЧТЧ, відхиленим у бік гіперкоагуляції: 34,8 \% проти 72,2 \% (p=0,039). Цікаво, що середнє значення АЧТЧ (як і всіх інших 3 показників коагулограми) серед осіб з тромбозами шунтів статистично значуще не відрізнялося від осіб без їх тромбозів. Все це свідчить про те, що прогностичне значення для тромбозу шунтів мають лише ті значення АЧТЧ, які виходять за межі норми (звичайно ж, в бік гіперкоагуляції).

Серед 8 осіб з 50-70\% стенозами в аортоклубовому сегменті та проведеними реконструктивними операціями лише на стегново-підколінному чи на стегново-підколінному і периферичному сегментах, частота тромбозів шунтів виявилася статистично значуще вищою, ніж у 9 осіб, у яких такі стенози були попередньо ліквідовані шляхом стентування зовнішньої чи загальної стегнової артерії: 83,3 \% проти 28,6 \% ( $\mathrm{p}=0,041)$. А отже, такі стенози варто ліквідовувати первинно.

Серед усіх хворих з одночасним ураженням аорто-клубового і стегново-підколінного артеріальних сегментів, оперованих лише на аорто-клубовому сегменті, симптоми ішемії, які спричиняли пацієнтам суттєвий дискомфорт (у одного - незагоєння трофічної виразки в ділянці латеральної кісточки та ще у двох - переміжна кільгавість < 200 м), залишилися лише у 3 осіб. Як виявилося, саме у цих осіб інтраопераційно виміряне відношення внутрішньоартеріа- льного середнього тиску у загальній стегновій артерії та середнього артеріального тиску на плечовій артерії виявилося вищим (від 0,55 до 0,70), ніж цей показник у будь-якого 3 хворих, які були цілком задоволені результатами оперативного втручання (від 0,12 до $0,49)$, причому різниця між показниками цих 2 підгруп була статистично значущою: $0,61(\sigma=0,08)$ проти $0,30(\sigma=0,13)(\mathrm{p}=0,005)$. Це свідчить про те, що значення інтраопераційно виміряного відношення внутрішньоартеріального середнього тиску у загальній стегновій артерії до середнього артеріального тиску на плечовій артерії $\geq 0,55$ може бути показом до одномоментної реконструкції і аорто-стегнового і стегново-підколінного артеріальних сегментів.

Серед 46 осіб з одномоментним ураженням стегново-підколінного і периферичного артеріальних сегментів у 17 хворих оперативне втручання проводилося лише на стегново-підколінному сегменті. У 11 3 них $(64,7 \%)$ наступив тромбоз шунта. Натомість серед 29 ідентичних хворих, у яких проводили одномоментну корекцію стегново-підколінного і периферичного артеріальних сегментів, тромбоз шунта відбувся у 13 осіб (44,8 \%). Не дивлячись на виражену тенденцію до меншої частоти тромбозів при реконструкції обох сегментів, різниця між цими показниками не була статистично значущою $(\mathrm{p}=0,233)$.

При стегново-підколінних шунтуваннях до підколінної артерії вище коліна частота тромбозів шунта не відрізнялася при аутовенозному шунтуванні, алошунтуванні та алоаутошунтуванні (у всіх випадках $\mathrm{p}>0,05)$. При стегново-підколінних шунтуваннях до підколінної артерії нижче коліна частота тромбозів аутовенозних шунтів склала 4 на 17 (23,5 $\%)$, алоаутовенозних - $435(80 \%)(\mathrm{p}=0,039)$ та алошунтів 2 з 4 (50,0 \%) (у обидвох випадках р > 0,05). При стегново-гомілкових шунтуваннях частота тромбозів аутовенозних шунтів склала 6 з 17 (35,3\%), алоаутовенозних - $236(33,3 \%)(p>0,05)$ та алошунтів 232 (100,0\%) (через невелику кількість таких пацієнтів у двох випадках $\mathrm{p}>0,05)$. Таким чином, аутовена $\epsilon$ трансплантатом вибору для будь-яких стегново-підколінних чи стегново-гомілкових шунтувань, але, при відсутності «адекватної» вени, алошунтування без високого ризику збільшення імовірності тромбозу шунтів можна використовувати лише для стегново-підколінних шунтувань 3 дистальним анастомозом вище коліна, а алоаутошунтування - для стегново-гомілкових реконструкцій.

Серед 26 пацієнтів, яким проводилися гомілкові шунтування чи протезування, у 7 осіб проксимальний анастомоз був сформований на підколінній артерії. У жодного з цих хворих впродовж 3 років не сталося тромбозу шунта $(0,0 \%)$. Це було рідше, ніж у осіб з проксимальним анастомозом на стегновій артеpiï (4 з 7; 57,1\%; p=0,070) та статистично значуще рідше при проксимальних анастомозах на загальній стегновій (5 з 10; 50,0\%; p=0,044) та зовнішній клубовій (2 з 2; 100,0 \%; p=0,028) артеріях. А отже, у всіх випадках, коли це можливо, проксимальний анастомоз при гомілкових шунтуваннях слід формувати 3 підколінною артерією. 
Щодо дистального анастомозу при гомілкових шунтуваннях, то статистично значущої різниці між різними гомілковими артеріями виявлено не було (у всіх випадках р >0,05).

Обговорення результатів. Вплив судиннотромбоцитарної ланки гемостазу на процеси тромбоутворення у пацієнтів 3 периферичним атеросклерозом вивчений досить ретельно, що сприяло рекомендаціям обов'язкового призначення таким пацієнтам антитромбоцитарних препаратів. [7, 8]. Існують також праці, які доводять, що агрегація тромбоцитів відіграє важливу роль у розвитку тромботичних ускладнень після реконструктивних операцій з використанням синтетичних трансплантатів. Осадження тромбоцитів на протезних трансплантатах було продемонстровано на кількох моделях тварин еx-vivo та in vivo i в організмі людини. При використанні 111індій мічених аутологічних тромбоцитів було продемонстровано, що тромбоцити нагромаджуються на дакронових аорто-стегнових протезах [9]. Проведене нами дослідження продемонструвало, що серед показників судинно-тромбоцитарного гемостазу в доопераційному періоді найбільш вагоме значення мають швидкість агрегації тромбоцитів та активність фактора фон Віллебранда, які були статистично значуще вищими у пацієнтів, у яких в подальшому сталися тромбози шунтів. Слід зауважити, що іншими дослідниками було виявлено, що підвищений рівень фоктора фон Віллебранда може виступати також у якості предиктора рестенозу зони реконструкції та прогресування атеросклерозу [10].

Якщо ж розглядати коагуляційну ланку гемостазу, то її вплив на тромбози периферичних шунтів вивчений значно менше. А рекомендації щодо тривалого вживання такими пацієнтами антикоагулянтів появилися лише менше року тому після отримання результатів багатоцентрового рандомізованого дослідження COMPASS, в якому було доведено, що тривалий прийом рівароксабану в дозі 2,5 мг двічі на добу у поєднанні з аспірином дозволяє зменшити частоту серцево-судинних подій та ішемічних подій з боку нижніх кінцівок, порівняно 3 прийомом виключно аспірину [11]. Однак в останніх міжнародних настановах щодо лікування пацієнтів 3 периферичними артеріальними захворюваннями прийом малих доз рівароксабану з аспірином розглядається як альтернатива монотерапії клопідогрелем [3]. При цьому диференціації, котрий з 2 варіантів лікування, кому обирати, в настановах не наведено. Наше дослідження показало, що єдиний зі скринінгових показників коагулограми, доопераційно знижений рівень якого є предиктором майбутнього тромбозу шунта, є АЧТЧ. А отже, первинне відхилення АЧТЧ в бік гіперкоагуляції могло б бути індикатором доцільності включення в лікувальну програму хворого тривалого прийому антикоагулянта. Однак, таке припущення необхідно ще довести додатковими дослідженнями.

На сьогоднішній день дискутабельним залишається питання, який ступінь стенозу в аортоклубовому сегменті (> 50 \% чи > 70 \%) вимагає корекції у випадку, якщо у пацієнта $є$ також оклюзійні ураження стегново-підколінного сегмента 3 необхід- ністю їх ліквідації. Якщо для загальної і глибокої стегнових артерій чітко визначено, що корекції вимагає стеноз > 50 \% [12], то для клубових артерій однозначної думки на сьогодні немає. Серед наших пацієнтів зі стенозами 50-70 \% в аорто-клубовому сегменті та протяжними оклюзіями у стегново-підколінному сегменті, яким реконструктивні операції виконували лише на стегново-підколінному сегменті, частота тромбозів шунтів виявилася статистично значуще вищою, ніж у осіб, у яких стенози в аорто-клубовому сегменті були нами попередньо ліквідовані шляхом стентування зовнішньої чи загальної клубової артерії. Такий результат є доказом того, що у подібних пацієнтів стенози 50-70 \% в аорто-клубовому сегменті слід теж ліквідовувати.

На сьогоднішній день не викликає сумнівів той факт, що аутовена є матеріалом вибору для реконструктивних операцій на стегново-підколінному та периферичному артеріальних сегментах [13]. Але коли достатньої довжини, придатної для шунтування аутовени у пацієнта немає, відкритим залишається питання: використовувати ало- чи алоаутошунтування. Проведене нами дослідження показало, що для стегново-підколінних шунтувань 3 дистальним анастомозом вище коліна без особливого збільшення ризику тромбозу шунта можна використовувати алошунтування, а для стегново-гомілкових реконструкцій - алоаутошунтування.

Особливо складним є питання доцільності «багатоповерхових» артеріальних реконструкцій при протяжних оклюзійних ураженнях кількох артеріальних сегментів нижньої кінцівки. Нова концепція «цільового артеріального шляху» передбачає магістралізацію кровотоку аж до стопи [3]. Але ця концепція стосується, головним чином, ендоваскулярних втручань при можливості їх виконання. Що ж до відкритих операцій, то однозначних рекомендацій на сьогодні немає. Результати, отримані нами у цьому дослідженні, продемонстрували, що 315 хворих з одночасним ураженням аорто-клубового i стегновопідколінного артеріальних сегментів, оперованих лише на аорто-клубовому сегменті, симптоми ішемії, які спричиняли виражений дискомфорт, залишилися лише у 3 осіб (20,0\%). А отже, одномоментна реконструкція аорто-клубового і стегново-підколінного сегментів була доцільною лише у кожного 5-го пацієнта. Але як саме визначити, чи потрібне «кількаповерхове» шунтування конкретному хворому. Наші дослідження показали, що у осіб 3 неліквідованими симптомами ішемії інтраопераційно виміряне відношення внутрішньоартеріального середнього тиску у загальній стегновій артерії до середнього артеріального тиску на плечовій артерії виявилося вищим, ніж цей показник у будь-якого з хворих, які були цілком задоволені результатами оперативного втручання, причому різниця між показниками цих 2 підгруп була статистично значущою. Поясненням, чому середнє відношення внутрішньоартеріального середнього тиску у загальній стегновій артерії до середнього артеріального тиску на плечовій артерії у пацієнтів зі збереженими симптомами ішемії було вищим, а не нижчим, на наш погляд, полягає в тому, що при одна- 
ково вираженій ішемії стопи, чим менший перепад тисків в аорто-клубовому сегменті, тим більший їх перепад у стегново-підколінному, і при ліквідації аорто-клубової оклюзії більші шанси збереження симптомів ішемії. 3 отриманих нами результатів можна зробити попередні висновки, що інтраопераційно виміряне значення відношення внутрішньоартеріального середнього тиску у загальній стегновій артерії до середнього артеріального тиску на плечовій артерії $\geq 0,55$ може бути показом до одномоментної реконструкції аорто-стегнового і стегново-підколінного артеріальних сегментів.

Оскільки вважається, що неспроможність дистального русла $є$ основною причиною невдалих реконструктивно-відновлювальних операцій на артеріях та причиною тромбозу $50 \%$ усіх шунтів $[14,15]$, то питання одномоментних втручань на стегновопідколінному і периферичному артеріальних сегментах набуває важливого значення. Отримані нами результати показали, що серед осіб з одномоментним ураженням стегново-підколінного і периферичного артеріальних сегментів, у яких оперативне втручання проводилося лише на стегново-підколінному сегменті, впродовж 3 років у 64,7 \% наступив тромбоз шунта. Натомість серед ідентичних хворих, у яких проводили одномоментну корекцію стегново-підколінного i периферичного артеріальних сегментів, тромбоз шунта відбувся у 44,8 \% випадків. I хоч різниця між цими показниками не була статистично значущою $(\mathrm{p}=0,233)$, бачимо чітку тенденцію до того, що одномоментна реконструкція стегново-підколінного i периферичного артеріальних сегментів дає кращі результати.

Не до кінця залишається вирішеним питання, від якої артерії варто проводити шунти до гомілкових артерій. В останній час превалює концепція найкоротшого шляху [13]. Проведені нами дослідження додатково підтвердили цю концепцію, оскільки серед 7 пацієнтів, яким проводилися гомілкові шунтування чи протезування 3 проксимальним анастомозом на підколінній артерії, у жодного не сталося тромбозу шунта, що було значно рідше, ніж у осіб з проксимальним анастомозом на стегновій артерії та статистично значуще рідше при проксимальних анастомозах на загальній стегновій $(\mathrm{p}=0,044)$ та зовнішній клубовій $(\mathrm{p}=0,028)$ артеріях.

\section{Висновки:}

1. Прискорення швидкості агрегації тромбоцитів, підвищення активності фактора Віллебранда та нижчі від норми значення активованого часткового тромбопластинового часу перед шунтуючими операціями на артеріях нижніх кінцівок можна вважати предикторами майбутнього тромбозу шунтів після реконструктивних операцій на артеріях нижніх кінцівок.

2. Серед осіб зі стенозами 50-70 \% в аортоклубовому сегменті та оклюзіями у стегновопідколінному сегменті, яким реконструктивні операції виконуються лише на стегново-підколінному сегменті, частота тромбозів шунтів статистично значуще вища, ніж у осіб, у яких стенози в аорто-клубовому сегменті попередньо ліквідуються шляхом стенту- вання зовнішньої чи загальної клубової артерії $(\mathrm{p}=0,041)$.

3. При відсутності придатної для шунтування аутовени відповідної довжини, для стегновопідколінних шунтувань 3 дистальним анастомозом вище коліна допустимо використовувати алошунтування, а для стегново-гомілкових реконструкцій алоаутошунтування.

4. У хворих із одночасним ураженням аортоклубового і стегново-підколінного артеріальних сегментів інтраопераційно виміряне значення відношення середніх артеріальних тисків у загальній стегновій та на плечовій артеріях $\geq 0,55$ може бути показом до одночасної реконструкції обох сегментів.

5. Серед пацієнтів, яким проводяться гомілкові реконструкції і проксимальний анастомоз формується на підколінній артерії, тромбози шунтів виникають рідше, ніж у осіб з проксимальним анастомозом на загальній стегновій $(\mathrm{p}=0,044)$ та зовнішній клубовій $(\mathrm{p}=0,028)$ артеріях.

6. Проведення нового дослідження з вивченням частоти тромбозів шунтів у випадку протидії виявленим у цій праці їх предикторам може зумовити суттєве покращення результатів лікування хворих 3 атеросклеротичними оклюзійно-стенотичними ураженнями.

\section{References:}

1. Fowkes FG, Rudan D, Rudan I, Aboyans V, Denenberg JO, McDermott MM et al. Comparison of global estimates of prevalence and risk factors for peripheral artery disease in 2000 and 2010: a systematic review and analysis. Lancet. 2013; 9901(382):1329-40 DOI: https://doi.org/10.1016/S0140-6736(13)61249-0

2. Norgren L, Hiatt WR, Dormandy JA, Nehler MR, Harris KA, Fowkes FG. Inter-society consensus for the management of peripheral arterial disease (TASC II). J Vasc Surg. 2007; 45(1):5-67. DOI: https://doi.org/10.1016/j.jvs.2006.12.037

3. Conte MS, Bradbury AW, Kolh P, White JV, Dick F, Fitridge $\mathrm{R}$ et al., Global vascular guidelines on the management of chronic limb-threatening ischemia. J Vasc Surg. 2019; 58(1):1-109 DOI: https://doi.org/10.1016/j.ejvs.2019.05.006

4. Kobza II, Soroka TH, Zhuk RA. Khirurhichne likuvannia patsiientiv pry infikuvanni proteziv aortostehnovoi zony. Klinichna khirurhiia. 2004; 4-5:8990.

5. Sarkysian AS. Khyrurhicheskoe lechenie trombozov i lozhnykh anevrizm alloprotezov posle pervichnykh rekonstruktivnykh operatsyi. Med. nauka Armenii. 2013; 2:87-94.

6. Hubka VO. Khirurhichne likuvannia uskladnen operatsii $\mathrm{u}$ khvorykh na obliteruiuchyi ateroskleroz aorty $\mathrm{i}$ arterii nyzhnikh kintsivok. Patolohiia. 2012; 24(1):89-91.

7. Delvaeye M, Conway EM. Coagulation and innate immune responses: can we view them separately? Blood. 2009; 114(12):2367-74. DOI: https://doi.org/10.1182/blood-2009-05-199208.

8. Connie N, Hess MD, Norgren L, Ansel GM, Capell WH, Fletcher JP, et al. A Structured Review of Antithrombotic Therapy in Peripheral Artery Disease With a Focus on Revascularization: a TASC 
(InterSociety Consensus for the Management of Peripheral Artery Disease) Initiative Antithrombotic Therapy After Peripheral Revascularization. Circulation. 2017; 135(25):2534-55. DOI: https://doi.org/10.1161/CIRCULATIONAHA.117.02446 9

9. Cassar1 K, Bachoo1 P, Brittenden J. The role of platelets in peripheral vascular disease. Eur J Vasc Endovasc Surg. 2003; 25(1):6-15. DOI: https://doi.org/10.1053/ejvs.2002.1795

10. Kalinin RE, Suchkov IA, Mzhavanadze ND, Klimentova YA, Zhurina ON. Pokazateli sistemy hemostaza $\mathrm{u}$ patsyentov $\mathrm{s}$ aterosklerozom peryferycheskikh arterii. Khirurhiia. Zhurnal im. N.Y. $\begin{array}{lll}\text { Pyrohova. } & \text { 2018; } & \text { (8):46-49 DOI: }\end{array}$ http://dx.doi.org/10.17116/hirurgia2018846

11. Anand SS, Bosch J, Eikelboom JW, Connolly SJ, Diaz R, Widimsky P, et al. Rivaroxaban with or without aspirin in patients with stable peripheral or carotid artery disease: an international, randomised, double-blind, placebocontrolled trial. Lancet. 2018; 10117(391):21929. DOI: https://doi.org/10.1016/S0140-6736(17)32409-1 12. Ballotta E, Gruppo M, Mazzalai F, DaGiau G. Commonfemoral artery endarterectomy for occlusive disease: an 8-year singlecenter prospective study. Surgery. 2010; 147(2):268-74. DOI: https://doi.org/10.1016/j.surg.2009.08.004

13. Aboyans V, Ricco JB, Bartelink MEL, Björck M, Brodmann M, Cohnert T et al. 2017 ESC Guidelines on the Diagnosis and Treatment of Peripheral Arterial Diseases, in collaboration with the European Society for Vascular Surgery (ESVS): Document covering atherosclerotic disease of extracranial carotid and vertebral, mesenteric, renal, upper and lower extremity arteriesEndorsed by: the European Stroke Organization (ESO)The Task Force for the Diagnosis and Treatment of Peripheral Arterial Diseases of the European Society of Cardiology (ESC) and of the European Society for Vascular Surgery (ESVS). Eur Heart J. 2018; 39(9):763816. DOI: https://doi.org/10.1093/eurheartj/ehx095

14.Vereshchahin SV, Akhmad MMD, Kucher VN, Hrabarchuk VP, Abramenko AV, Shulha VN ta in. Endovaskuliarnoe lechenie i profilaktika pozdnikh ostrykh trombozov posle rekonstruktivnykh operatsyi na arteriiakh nizhnikh konechnostei. Endovaskuliarna neirorenthenokhirurhiia. 2016; 17(3):58-76. Available from: http://nbuv.gov.ua/UJRN/evnh_2016_3_10 15. Kalinin RE, Suchkov IA, Chobanian A $\bar{A}$. Perspektivy prohnozirovaniia techeniia obliteriruiushcheho ateroskleroza arterii nizhnikh konechnostei. Nauka molodykh (Eruditio Juvenium). 2019; 7(2):274-282. DOI: http://dx.doi.org/10.23888/HMJ201972274-282

\section{УДК 575.191+616-005.6+616-089+616.13+617.58 ПРЕДИКТОРЫ ТРОМБОЗА ШУНТОВ У ПАЦИЕНТОВ С АТЕРОСКЛЕРОТИЧЕСКИМИ ОККЛЮЗИОННО-СТЕНОТИЧЕСКИМИ ПО- РАЖЕНИЯМИ АРТЕРИЙ НИЖНИХ КОНЕЧНОСТЕЙ}

Р.В. Сабадош, В.А. Решетило, О.Ф. Совтус, B.В. Мотуз, С.В. Сарапук, Н.М. Ризюк

Ивано-Франковский нацииональный медииинский университет, кафедра хирургии стоматологического факультета, г. Ивано-Франковск, Украина,

ORCID ID: 0000-0001-9770-5960,

ORCID ID: 0000-0001-6216-3524,

ORCID ID: 0000-0001-9125-7570,

ORCID ID: 0000-0002-9369-7518,

ORCID ID: 0000-0001-8678-8801,

ORCID ID: 0000-0003-0364-666X,

e-mail:r.sabadosh@gmail.com

Резюме. Целью работы стало улучшение лечения больных облитерирующим атеросклерозом нижних конечностей, которым проводятся открытые шунтирующие операции на артериях, путем изучения частоты и причин тромбозов шунтов после реконструктивных операций на различных артериальных сегментах. В течение 3 лет динамично наблюдали за 93 такими больными. У 81 больного были выполнены «одноэтажные» реконструктивные вмешательства и у 12 - «двухэтажные». Было обнаружено, что у лиц, у которых за это время произошли тромбозы шунтов, скорость агрегации тромбоцитов и уровень фактора фон Виллебранда перед операцией были статистически значимо выше, чем у больных без тромбозов шунта $(p=0,037$ и 0,048$)$. Частота тромбозов шунтов была также статистически значимо выше у лиц с дооперационным значением активированного частичного тромбопластинового времени, отклоненным в сторону гиперкоагуляции $(\mathrm{p}=0,039)$. Среди лиц со стенозом 50-70\% в аорто-подвздошном сегменте и окклюзиями в бедренно-подколенном сегменте, которым реконструктивные операции выполняли только на бедренно-подколенном сегменте, частота тромбозов шунтов оказалась статистически значимо выше, чем у лиц, у которых стеноз в аорто-подвздошном сегменте был предварительно ликвидирован путем стентирования внешней или общей подвздошной артерии $(p=0,041)$. Было также установлено, что при отсутствии «адекватной» вены, аллошунтирование допустимо применять для бедренно-подколенных реконструкций с дистальным анастомозом выше колена, а аллоаутошунтирование - для бедренноберцовых. Проведение нового исследования с изучением частоты тромбозов шунта в случае противодействия выявленным в этой работе их предикторам может вызвать существенное улучшение результатов лечения больных.

Ключевые слова: облитерирующий атеросклероз, тромбозы шунтов, гемостаз. 
UDC 575.191+616-005.6+616-089+616.13+617.58

PREDICTORS OF BYPASS GRAFT THROMBOSIS IN PATIENTS WITH PERIPHERAL ARTERY DISEASE

R.V. Sabadosh, V.A. Reshetylo, O.F. Soutus, V.V. Motuz, S.V. Sarapuk, N.M. Ryziuk

Ivano-Frankivsk National Medical University, Department of Surgery of Faculty of Dentistry,

Ivano-Frankivsk, Ukraine,

ORCID ID: 0000-0001-9770-5960,

ORCID ID: 0000-0001-6216-3524,

ORCID ID: 0000-0001-9125-7570,

ORCID ID: 0000-0002-9369-7518,

ORCID ID: 0000-0001-8678-8801,

ORCID ID: 0000-0003-0364-666X,

e-mail:r.sabadosh@gmail.com

Abstract. The problem of bypass graft thrombosis at peripheral artery disease is one of the most important problems of vascular surgery.

The aim of this work was to improve the treatment of patients with peripheral artery disease who undergo open bypass surgery by examining the frequency and causes of bypass graft thrombosis after reconstructive surgery in different arterial segments.

Materials and methods. 93 patients with peripheral artery disease who underwent bypass surgery on different segments of the lower limb arteries were dynamically observed for 3 years. 81 patients underwent bypass surgery on one segment of the lower limb arteries and 12 patients underwent such surgery on two segments.

Results of the study. It was found out that in patients who had bypass graft thrombosis within 3 years of observation, platelet aggregation rate and Willebrand factor level before surgery were statistically significantly higher than in patients without bypass graft thrombosis ( $p$ $=0.037$ and 0.048 ). Among persons with pre-operative normal or hypocoagulation meanings of activated partial thromboplastin time, the frequency of bypass graft thrombosis was statistically significantly lower than in persons with hypercoagulation meanings of this time $(\mathrm{p}=$ 0.039 ). Among persons with $50-70 \%$ stenosis in the aorta-iliac segment and occlusion in femora-popliteal seg- ment who underwent reconstructive operations only in the femora-popliteal segment, the frequency of bypass graft thrombosis was statistically significantly higher than in those who had stenosis in the aorta-iliac segment previously resolved by the external or common iliac artery stenting $(\mathrm{p}=0.041)$. Among patients with concomitant lesions of the aorta-iliac and femoro-popliteal segments who underwent reconstructive operations only in the aorta-iliac segment and still had unresolved symptoms of ischemia, intraoperatively measured ratio of average invasive blood pressure in the common femoral to the average blood pressure in the upper arm appeared to be statistically significantly higher than in patients with resolved symptoms of ischemia: $0.61(\sigma=0.08)$ versus $0.30(\sigma=0.13)(\mathrm{p}=0.005)$. At femoro-popliteal bypass grafting with distal anastomosis on the popliteal artery above the knee the frequency of bypass graft thrombosis did not differ at vein, prosthetic and combined prosthetic and vein bypass grafting $(\mathrm{p}>0.05)$. When applying the same anastomosis to the popliteal artery below the knee the frequency of thrombosis of vein bypass grafts was significantly lower than for combined prosthetic and vein bypass grafts $(p=0.039)$ and tended to be lower than for prosthetic bypass grafts $(\mathrm{p}>0.05)$. At femoro-distal bypass grafting the frequency of vein bypass graft thrombosis was not statistically significantly different from the frequency of combined prosthetic and vein bypass graft thrombosis ( $p>0.05)$, and each of them tended to be significantly lower than the frequency of prosthetic bypass graft thrombosis. Among patients undergoing distal reconstruction and who had proximal anastomosis formed on the popliteal artery, thrombosis of the bypass grafts occurred less frequently than in persons with proximal anastomosis on the common femoral $(p=0.044)$ and external iliac $(\mathrm{p}=0.028)$ arteries.

Conclusion. Carrying out a new study examining the frequency of bypass graft thrombosis in case of counteraction proved in these study predictors of this thrombosis may lead to a significant improvement in treatment outcomes for such patients.

Keywords: peripheral artery disease, bypass graft thrombosis, hemostasis.

Стаття надійшла в редакцію 06.12.2019 р. 